\title{
$\begin{array}{lllllllllllllllll}\mathbf{R} & \mathbf{O} & \mathbf{Z} & \mathbf{P} & \mathbf{R} & \mathbf{A} & \mathbf{W} & \mathbf{Y} & \text { I } & \text { A } & \mathbf{R} & \mathbf{T} & \mathbf{Y} & \mathbf{K} & \mathbf{U} & \mathbf{L} & \mathbf{Y}\end{array}$
}

Prawo Kanoniczne

63(2020) nr 2

DOI:10.21697/pk.2020.63.2.01

KS. JERZY ADAMCZYK

Wyższe Seminarium Duchowne w Radomiu

ORCID: 0000-0003-1415-7378

\section{STAN DZIEWIC KONSEKROWANYCH. PRAWO DZIEWIC DO ZRZESZANIA SIE. ASPEKT PRAWNO-KANONICZNY}

Treść: Wstęp. - 1. Dziewictwo konsekrowane w Kościele w aspekcie historycznym. - 2. Definicja stanu dziewictwa konsekrowanego. - 3. Prawo dziewic konsekrowanych do zrzeszania się. - Podsumowanie.

\section{Wstęp}

31 maja 1970 r. Święta Kongregacja ds. Kultu Bożego, z nakazu Papieża św. Pawła VI, ogłosiła nowy Obrzęd Konsekracji Dziewic, odnowiony zgodnie z postanowieniami Soboru Watykańskiego II, który wszedł w życie dnia 6 stycznia 1971 r. Sobór polecił przejrzenie rytuału konsekracji dziewic, znajdującego się w Pontyfikale Rzymskim. Miało to na celu nie tylko staranne przejrzenie formuł liturgicznych i gestów obrzędowych, ale także przywrócenie obrzędu, który w odniesieniu do kobiet nie należących do instytutów życia konsekrowanego od wieków nie był używany. Wraz z tym rytem został przywrócony stan dziewic, Ordo virginum, który znalazł swe własne sformułowanie prawne, różne od instytutów z kan. 599 aktualnego Kodeksu Prawa Kanonicznego. Ten odnowiony obrzęd i przywrócone Ordo są podwójnym darem Pana dla Jego Kościołaํ. Papież Franciszek

\footnotetext{
${ }^{1}$ Por. Jan PaweŁ II, Przemówienie Ojca Świętego Jana Paweł II „Niech Chrystus będzie waszą całkowitą i wyłaczną miłością" (2 czerwca 1995), nr 1, www.konsekrowane.org (dostęp 16.09.2020); por. Prefekt Kongregacji ds. Instytutów Życia
} 
przemawiając do dziewic konsekrowanych z okazji pięćdziesięciolecia promulgacji Obrzędu Konsekracji Dziewic zaznaczył, że: „Forma waszego życia znajduje swoje pierwsze źródło w Obrzędzie, swoją konfigurację prawną ma w kanonie 604 Kodeksu Prawa Kanonicznego, a od roku 2018 w Instrukcji Ecclesiae Sponsae Imago"2.

$\mathrm{Z}$ roku na rok przybywa na świecie konsekrowanych dziewic ${ }^{3}$. $\mathrm{Pa}-$ pieże i kongregacje rzymskie poświęcają wiele uwagi temu odradzającemu się stanowi życia w Kościele. Stąd cenną rzeczą będzie ukazanie stanu dziewic w aspekcie prawno-kanonicznym. Pociąga to za sobą próbę dania odpowiedzi na pojawiające się różne pytania-problemy: jak w ciągu wieków kształtowała się instytucja dziewic konsekrowanych, kim w optyce kanonicznej jest dziewica konsekrowana, jakie winna mieć przymioty, kto dopuszcza do ślubów czy innych świętych więzów? Zasygnalizowanym i innym problemom zostanie poświęcony niniejszy artykuł. Należy dodać, że przedmiotem tego tekstu będą dziewice konsekrowane żyjące w świecie. Stąd nie będą brane pod uwagę konsekrowane mniszki, z racji na podobieństwo ich stylu życia do życia zakonnego.

\section{Dziewictwo konsekrowane w Kościele $\mathrm{w}$ aspekcie historycznym}

Jest pewne, że już we wczesnych wspólnotach chrześcijańskich byli mężczyźni i kobiety, którzy wybierali stan dziewiczy lub celibat, jako

Konsekrowanego i Stowarzyszeń Życia Apostolskiego, List do dziewic konsekrowanych (21 maja 2020), www.konsekrowane.org (dostęp 16.09.2020).

${ }^{2}$ Messaggio del Santo Padre Francesco nel 50 anniversario della Promulgazione del Rito della Consacrazione delle vergini, „Bollettino Sala Stampa Della Santa Sede”, s. 11, wersja elektroniczna, https://press.vatican.va/ (dostęp 15.09.2020).

${ }^{3}$ Coraz więcej kobiet partycypuje w ordo virginum. Szukają one bardziej odpowiedniego, eklezjalnego wyrazu swojej charyzmatycznej tożsamości. We Włoszech w 1992 r. odbyła się piąta krajowa konferencja poświęcona dziewicom. Ich biuletyn informacyjny „Sponsa Christi” dociera do około stu dziewic konsekrowanych. W różnych diecezjach sporządzono statuty regulujące warunki ich życia w danym Kościele. S. Recchi, L’ordine delle vergini, Quaderni di Diritto Ecclesiale 5 (1992), nr 2, s. 141. Tak było w 1992 r. Przez lata na całym świecie wzrasta liczba dziewic konsekrowanych. 
stabilny stan życia, w którym mogliby wyrazić całkowite oddanie się Chrystusowi i miłość do Kościoła. Już w początkach Kościoła konsekrowano dziewice według uroczystego rytu, przez który stawały się one osobami konsekrowanymi. Dziewice w tamtym czasie mieszkały ze swoimi rodzinami albo we własnych domach. W swojej posłudze były do dyspozycji Kościoła, przede wszystkim przez modlitwę i pełnienie dzieł miłosierdzia ${ }^{4}$.

Dziewice konsekrowane zajmowały już w Kościele pierwszych wieków w zgromadzeniach liturgicznych miejsce szczególne - zaraz po duchowieństwie. Ta forma życia była wówczas bardzo popularna. W tekstach z tego okresu dziewice konsekrowane są przedstawiane, podobnie jak biskupi, kapłani, diakoni i wdowy, jako szczególna kategoria wiernych, ciało ukonstytuowane w Kościele, wobec którego św. Bazyli mógł się posłużyć wyrażeniem „ordo virginum”.

W IV w. istniał już obrzęd konsekracji dziewic ${ }^{6}$. Istnieją bezsporne wiadomości o celebracji liturgicznej, w której wybór dziewicy był przyjmowany publicznie w ramach wspólnoty. Obrzęd ten, wzorowany na obrzędzie małżeństwa, musiał być dość prosty: podczas celebracji eucharystycznej biskup wyjaśniał w homilii znaczenie gestu, który miał wykonać, odmawiał modlitwę i zakładał flammeum, czerwony welon, który zakładano na głowę panny młodej podczas ślubu?

${ }^{4}$ Por. E. Bolchi, La consacrazione nell'Ordo virginum: forma di vita e disciplina canonica, Editrice Pontifìcia Università Gregoriana, Roma 2002, s. 13; por. Stan dziewic. Materiały pomocnicze dla kościoła w Polsce. Część pierwsza - wskazania ogólne, s. 1, www.konsekrowane.org (dostęp 16.06.2020).

${ }^{5}$ E. Bolchi, La consacrazione nell'Ordo virginum: forma di vita e disciplina canonica, s. 15.

${ }^{6} \mathrm{G}$. Bartoszewski, Prawne podstawy dla indywidualnych form życia konsekrowanego, www.konsekrowane.org (dostęp 16.06.2020).

${ }^{7}$ E. Bolchi, La consacrazione nell'Ordo virginum: forma di vita e disciplina canonica, s. 14; zob. P. WALKIEwICz, Dziewictwo płodne - ideał konsekracji osoby, w: Mulieris dignitas. Promieniowanie kobiecości, red. T. Paszkowska, Wydawnictwo KUL, Lublin 2009, s. 294; zob. M. Dion, La consécration des vierges. Implications juridiques, Thèse présentée à la Faculté de Droit canonique de l'Université Saint-Paul Ottawa, pour l'obtention du doctorat en droit canonique, Ottawa, 1983, s. 134-135. 
Trzeba dodać, że sposób życia dziewic konsekrowanych nie był nakreślony jedynie w tekstach patrystycznych: niekiedy były ustanawiane normy dyscyplinarne odnoszące się do dziewic, także na synodach prowincjalnych. Dla dziewic konsekrowanych, które nie wywiązały się ze swoich zobowiązań, przewidziano surowe kary, a także nakładano sankcje na ich rodziny, jeśli były to osoby zajmujące ważne stanowiska we wspólnocie chrześcijańskiej.

Uroczysty liturgiczny obrzęd konsekracji pozwalał odróżnić dziewice, które należały do stanu konsekrowanego uznanego przez Kościół, od tych, które poświęciły się Bogu na mocy zobowiązań prywatnych, to znaczy między virgines velatae i virgines nondum velatae ${ }^{9}$.

Jednocześnie dziewice konsekrowane rozpowszechniają praktykę życia wspólnego, zarówno na Wschodzie, jak i na Zachodzie. Przez kilka wieków istniały więc dwa różne sposoby przeżywania konsekracji: niektóre dziewice konsekrowane pozostawały w obrębie miejscowej wspólnoty, mieszkając we własnych domach; inne tworzyły wspólnoty, które następnie zostały obdarzone regułą i z czasem nabrały charakteru wspólnot zakonnych ${ }^{10}$.

Stopniowo zmniejszała się liczba dziewic konsekrowanych liturgicznie, które mieszkały we własnych domach lub we wspólnotach niemonastycznych. Już pod koniec IV w. pojawił się przepis, który zdecydowanie promował życie wspólnotowe dziewic: w 397 r. III Synod w Kartaginie zarządził, że dziewice konsekrowane in saeculo, pozbawione wsparcia członków swojej rodziny, powinny przyjąć życie wspólnotowe ${ }^{11}$. Mniej więcej cztery wieki później Karol Wielki w Kapitularium Akwizgrańskim z 789 r. przywrócił dyspozycję

\footnotetext{
${ }^{8}$ E. Bolchi, La consacrazione nell'Ordo virginum: forma di vita e disciplina canonica, s. 17-18. Np. kan 19 I Synodu w Toledo (400 r.) przewidział ekskomunikę rodziców, którzy przyjęli upadłą (lapsa) dziewicę konsekrowaną. Por. tamże, s. 18.

${ }^{9}$ E. Bolchi, La consacrazione nell'Ordo virginum: forma di vita e disciplina canonica, s. 17-18.

${ }^{10}$ Tamże, s. 19-20.

${ }^{11}$ J. StegmaIl, „Mystically Espoused to Christ, the Son of God (c. 604 \$ 1)”: The Basis for Proposing Juridic Principles to Guide the Development of Norms for the Ordo virginum. Doctoral dissertation, Washington 2019, s. 85.
} 
Synodu w Kartaginie, podsumowując jej znaczenie w następujący sposób: „w Synodzie Afrykańskim nakazuje się, aby dziewice konsekrowane Bogu zostały powierzone starannej opiece ludzi mądrych i roztropnych"12.

W Rzymie, podczas najazdów barbarzyńskich, przybywało wspólnot dziewic konsekrowanych, zwłaszcza w okresie pontyfikatu papieża Grzegorza Wielkiego (590-604), który wspierał powstawanie nowych klasztorów. Jednak były dziewice nadal mieszkające w swoich domach. Synody Orleański V (549) i Synod Paryski V (615) wydały przepisy odnoszące się do młodych kobiet, które podejmując decyzję życia w czystości, nadal mieszkały w swoich własnych domach; dla tych dziewic, które nie wywiązały się ze swoich zobowiązań, przewidziana była kara ekskomuniki ${ }^{13}$.

Badacze uważają za niemożliwe dokładne wskazanie, kiedy starożytny obrzęd velatio zaczął być stosowany tylko w klasztorach - choć faktycznie nie we wszystkich, ponieważ poza nielicznymi wyjątkami, zakony żebrzące zostały z tego zwyczaju wyłączone. Kanon 26 Soboru Laterańskiego III z 1139 r., często przywoływany w tej kwestii, w rzeczywistości nie zawiera formalnego i wyraźnego zakazu przystępowania do konsekracji dziewic żyjących w świecie. Pozbawiał jednak eklezjalnego uznania takiej formy życia kobiet, które chciały żyć w bezżeństwie bez wstępowania do klasztoru, z obawy przed wypaczeniami i nadużyciami, które mogłyby się pojawić przy braku gwarancji i ochrony, jakie daje życie wspólnotowe prowadzone w ramach danej reguły ${ }^{14}$.

\footnotetext{
${ }^{12}$ E. Bolchi, La consacrazione nell'Ordo virginum: forma di vita e disciplina canonica, s. 20.

${ }^{13}$ Tamże, s. 20-21; por. M. Dion, La consécration des vierges. Implications juridiques, s. 139.

${ }^{14}$ Conciuum Lateranense II (1139), can. 26: „Perniciosam et detestabilem consuetudinem quarundarum mulierum, quae licet neque secundum regula beaii Benedicti, neque Basilii aut Augustini vi vant, Sanctimoniales lamen vulgo censen desideram, aboleri decemimus. Cum enim iuxta regulam degentes in coenobiis, tam in Ecclesia quam in refectorio atque dormitorio communiter esse debeant, propria sibi a edificant receptacula et privata domicilia, in quibus sub hospitalitatis
} 
Tak więc instytucja dziewictwa konsekrowanego była żywotna do końca XI w. Jest zaskakujące, że kiedy zaczyna zanikać w Kościele zwyczaj udzielania konsekracji dziewicom żyjącym w świecie, pojawia się po raz pierwszy obrzęd przewidziany na te okazje. Zawiera go Pontyfikał rzymsko-germański, sporządzony około 950 r. przez anonimowego mnicha z opactwa św. Albana w Moguncji, który wprowadza do obrzędów konsekracji stosowne rozróżnienie miedzy dziewicami, które żyją w klasztorach, a tymi, które żyją w świecie. Tekst przywołanego Pontyfikału jest szczególnie interesujący, ponieważ zawiera dwa schematy rytu: jeden dla konsekracji kobiet klauzurowych, który jest bardzo szeroki i rozbudowany, a drugi, prostszy, dla kobiet, które chcą żyć w stanie dziewiczym poza wspólnotą klasztorną. Była to nowość w porównaniu z poprzednimi tekstami liturgicznymi, które nie przewidywały takiego rozróżnienia. Zdaniem uczonych stanowi ona pośrednie, ale bardzo znaczące świadectwo tego, że przynajmniej w X w. w środowisku franko-germańskim consecratio virginum była celebrowana i funkcjonowała poza instytucją zakonną ${ }^{15}$.

Mimo tych dążeń praktyka konsekracji zanikała. Formularzy konsekracji nie zamieszczały wydawane później pontyfikały np. Pontyfikał Rzymski. Od XVI w. chociaż dziewictwo kobiet było nadal w wielki poważaniu i było uznawane za wielki dar Boży dla życia duchowego Kościoła, to jednak zwyczaj sprawowania obrzędu konsekracji całkowicie zanikł16. Bowiem nie tylko rytuał konsekracji przestał

velamine passim hospites et minus religiosos, contra sacros canones et bonos mores, suscipere nullatenus erubescunt. Quia ergo omnis qui male agit odit lucem, ac per hoc ipsae absconditae in injustorum tabernaculo opinantur se posse latere oculos judicis cuneta cernentis: hoc tam inhonestum detestandumque flagitium ne ulterius fíat, omnimodis prohibemus, et sub poena anathematis interdicimus". G. MansI, Sacrorum Conciliorum nova et amplissima collectio, vol. XXI, Venetiis 1776, col. 531-532; por. E. BolCHI, La consacrazione nell'Ordo virginum: forma di vita e disciplina canonica, s. 21.

${ }^{15} \mathrm{E}$. Bolchi, La consacrazione nell'Ordo virginum: forma di vita e disciplina canonica, s. 23; por. M. Dion, La consécration des vierges. Implications juridiques, s. 86 .

${ }^{16} \mathrm{G}$. Bartoszewski, Prawne podstawy dla indywidualnych form $\dot{z} y c i a$ konsekrowanego. 
być stosowany w odniesieniu do dziewic żyjących na świecie, ale wraz z rozprzestrzenianiem się klauzury i ograniczaniem konsekracji dziewic do tych, które znajdują się we wspólnotach zamkniętych, konsekracja stała się rzadkością, nawet dla dziewic klauzurowych. Św. Karol Boromeusz podczas IV Synodu diecezjalnego w Mediolanie w 1576 r. na próżno starał się ożywić zwyczaj uroczystego poświęcania dziewic w klasztorach ${ }^{17}$. Co więcej, przez długi czas nie pojawiły się akty normatywne o charakterze ogólnym odnoszące się do consecratio virginum, choć były jednak pewne interwencje Świętej Kongregacji Obrządków i Świętej Kongregacji Zakonów w odpowiedzi na konkretne problemy i przypadki ${ }^{18}$.

Gdy idzie o wiek XX, to od roku 1922 zaczęły do Świętej Kongregacji Zakonów napływać pytania na temat dziewictwa konsekrowanego dla kobiet żyjących w świecie, zwłaszcza z Francji i Belgii. Po zebraniu tych głosów przez konsultorów Święta Kongregacja Zakonników na sesji plenarnej 25 lutego 1927 r. rozpatrywała wątpliwość: „czy właściwym jest zezwolić na udzielanie błogosławieństwa i konsekracji dziewic, kobietom żyjącym w świecie?"19. Decyzja zgromadzenia plenarnego została następnie zatwierdzona i aprobowana przez Piusa XI, który zarządził jej publikację w „Acta Apostolicae Sedis”. Była to odpowiedź negatywna, która uniemożliwiała wprowadzenie zmian

\footnotetext{
${ }^{17}$ Ustawodawstwo mediolańskie musiało uwzględniać ścisłe zasady dotyczące klauzury obowiązujące w okresie potrydenckim. Kan. 21 IV Synodu w Mediolanie z 1576 r. brzmiał: „Ubi religiosus iste et vetus Moniales, solemniter velandi mos his temporibus antiquatus est, ad pristinum usum ex veteri instituto et ritu revocetur, dummodo intra monasterio id fiat". G. MANSI, Sacrorum Conciliorum nova et amplissima collectio, vol. XXXIV, Parisis 1902, col. 322; por. J. STEGMAIL, „Mystically Espoused to Christ, the Son of God (c. $604 \$ 1$ ), s. 94.

${ }^{18}$ Por. E. Bolchi, La consacrazione nell'Ordo virginum: forma di vita e disciplina canonica, s. 26.

${ }^{19}$ Sacra Congregatio de Religiosis, Responsum ad dubium: De consecratione virginum pro mulieribus in saeculo viventibus (25 Martii 1927), „Acta Apostolicae Sedis”, 56 (1927), s. 138-139: dubium: „An expediat concedere facultatem dandi benedictionem et consecrationem virginum mulieribus in saeculo viventibus". Responderunt: „Negative, et nihil innovetur”.
} 
w tej kwestii. Mimo to w kolejnych latach do Świętej Kongregacji Zakonów nadal docierały inne podobne petycje i zapytania ${ }^{20}$.

W 23 lata później, 21 listopada 1950 r. papież Pius XII w konstytucji „Sponsa Christi” wyjaśnił, że obrzęd konsekracji dziewic zastrzeżony jest wyłącznie dla mniszek. Papież pisał: „Starożytne, uroczyste formuły konsekracji dziewic, znajdujące się w Pontyfikale Rzymskim, są zarezerwowane dla mniszek” ${ }^{21}$ W „Sponsa Christi” zauważono, że na początku średniowiecza zanikł stan dziewic konsekrowanych żyjących poza klasztorami i stwierdzono, że mniszki były uważane za jedynych uprawnionych spadkobierców starożytnych dziewic konsekrowanych ${ }^{22}$. Pius XII potwierdził więc związek między consecratio virginum a doświadczeniem klasztornym. Tak zostało to również ukazane w Statuta generalia monialium promulgowanym 21 listopada 1950 r. przez tegoż papieża. Zamiarem Piusa XII było ponowne zaproponowanie i przywrócenie w dyscyplinie całego Kościoła istotnych elementów kanonicznych figury monastycznego życia kontemplacyjnego ${ }^{23}$.

Sobór Watykański II w Konstytucji o Liturgii uchwalonej 4 grudnia 1963 postanowił: „Należy rozpatrzyć krytycznie obrzęd konsekracji dziewic, znajdujący się w Pontyfikale Rzymskim”24 i autorytatywnie

\footnotetext{
${ }^{20}$ E. Bolchi, La consacrazione nell'Ordo virginum: forma di vita e disciplina canonica, s. 31; por. M. Dion, La consécration des vierges. Implications juridiques, s. 65.

${ }^{21}$ „Solemnes antiquae formulae consecrationis Virginum, quae in Pontificali Romano habentur, Monialibus reservantur". PIUs PP. XII, Statuta generalia monialium (21 Novembris 1950), art. III \$3, „Acta Apostolicae Sedis” 43 (1951), s. 16; por. J. Stegmail, „Mystically Espoused to Christ, the Son of God (c. 604 \$ 1), s. 3.

${ }^{22}$ Por. Pius PP. XII, Constitutio Apostolica Sponsa Christi (21 Novembris 1950), „Acta Apostolicae Sedis” 43 (1951), s. 7; por. E. Bolchi, La consacrazione nell'Ordo virginum: forma di vita e disciplina canonica, s. 35.

${ }^{23}$ Por. E. Bolchi, La consacrazione nell'Ordo virginum: forma di vita e disciplina canonica, s. 35.

${ }^{24}$ Concilium Oecumenicum Vaticanum II, Constitutio de sacra Liturgia: Sacrosanctum Concilium (4 Decembris 1963), nr 80, „Acta Apostolicae Sedis”, 56 (1964), s. 97-138, tekst polski: Sobór Watykański II, Konstytucja o liturgii świętej Sacrosanctum Concilium, w: Sobór Watykański II. Konstytucje, dekrety, deklaracje.
} 
przypomniał i wydobył ze skarbca liturgicznego Kościoła starożytnego obrzędu konsekracji, a przez to wskrzesił do życia stan dziewic, będący u podstaw dawnych i współczesnych form życia konsekrowanego. W konsekwencji dnia 31 maja 1970 r. Kongregacja Kultu Bożego, wykonując polecenie Soboru, oficjalnie ogłosiła nowe obrzędy konsekracji dziewic ${ }^{25}$. Było to faktyczne, po ośmiu wiekach przerwy, przywrócenie możliwości udzielania konsekracji dziewicom chrześcijańskim żyjącym w świecie, czyli stanu dziewic konsekrowanych żyjących poza zakonami.

Kodeks Prawa Kanonicznego z 1983 r. ${ }^{26}$ dziewice konsekrowane włączył do kanonicznie zatwierdzonych indywidualnych form życia konsekrowanego, poświęcając im kan. 604, gdzie w $\$ 1$, przedstawia się definicję prawną dziewicy konsekrowanej, a w $\$ 2$ mówi się o sposobie życia tych kobiet, mianowicie, że dziewice konsekrowane mogą żyć osobno lub tworzyć jakąś wspólnotę, jako stowarzyszenie.

Wreszcie Kongregacja ds. Instytutów Życia Konsekrowanego i Stowarzyszeń Życia Apostolskiego dnia 8 czerwca 2018 r. opublikowała instrukcję na temat ordo virginum, zatytułowaną Ecclesiae Sponsae

Tekst polski. Nowe tłumaczenie, Wydawnictwo Pallottinum, Poznań 2002, s. 48-78; por. G. BARtoszewski, Prawne podstawy dla indywidualnych form życia konsekrowanego; por. E. BolCHI, La consacrazione nell'Ordo virginum: forma di vita e disciplina canonica, s. 62. Trzeba dodać, że ojcowie soborowi polecając rewizję obrzędu poświęcenia dziewic pragnęli, aby korzystanie z niego zostało ponadto rozszerzone na instytuty świeckie i na kobiety prowadzące życie w dziewictwie w świecie. A. Martimort, The Church at prayer. An Introduction to the Liturgy. New Edition Vol. III, The Sacraments, translated by M. O'Connell, The Liturgical Press, Collegeville, Minnesota 1988, s. 210.

${ }^{25}$ Pontificale Romanum ex Decreto Sacrosancti Concilii cumenici Vaticani II instauratum auctoritate Pauli PP. VI promulgatum, Ordo Consecrations Virginum, Editio typica, Typis Polyglottis Vaticanis, Città del Vaticano 1978, tekst polski: Pontyfikał Rzymski, Obrzędy konsekracji dziewic, Wydanie wzorcowe, Wydawnictwo Księgarnia św. Jacka, Katowice 2001, (odtąd: OCV).

${ }^{26}$ Codex Iuris Canonici auctoritate Ioannis Pauli PP. II promulgatus, Acta Apostolicae Sedis 1983, pars II, s. 1-317; tekst polski Kodeks Prawa Kanonicznego, przekład polski zatwierdzony przez Konferencję Episkopatu, Wydawnictwo Pallottinum, Poznań 1984, (odtąd: KPK). 
Imago ${ }^{27}$. Tak więc stan dziewic znajduje obecnie swoje umocowania prawne w kan. 604 KPK, a od roku 2018 w Instrukcji Ecclesiae Sponsae Imago ${ }^{28}$.

\section{Definicja stanu dziewictwa konsekrowanego}

Mając na uwadze współczesne warunki, ustawodawca kościelny wprowadził dwie nowe formy życia konsekrowanego: życie pustelnicze i stan dziewic. Prawodawca mówi o nich w normach wspólnych, ponieważ osoby prowadzące ten rodzaj życia nie są członkami instytutów zakonnych czy instytutów świeckich ${ }^{29}$. Stan dziewic, jak i życie pustelnicze stanowią indywidualne powołania lub formy życia konsekrowanego, gdyż jego członkowie nie żyją w grupach i nie realizują wspólnego charyzmatu ${ }^{30}$.

Kodeks Prawa Kanonicznego i instrukcja Ecclesiae Sponsae Imago Kongregacji ds. Instytutów Życia Konsekrowanego i Stowarzyszeń Życia Apostolskiego z 2018 r. stanowią podstawę prawną istnienia i funkcjonowania instytucji dziewic konsekrowanych w perspektywie Kościoła Powszechnego. Podstawę liturgiczną i prawną stanowi także „Obrzęd konsekracji dziewic” (Ordo consecrationis virginum) opublikowany przez Kongregację Kultu Bożego i Dyscypliny Sakramentów

\footnotetext{
${ }^{27}$ Congregazione per gli Istituti di Vita Consacrata e le Società di Vita ApostolicA, Istruzione sull'ordo virginum Ecclesiae sponsae imago (8 giugno 2018), Libreria Editrice Vaticana, Città del Vaticano 2018, tekst polski: Ecclesiae Sponsae Imago. Instrukcja na temat ordo virginum, Wydawnictwo Bernardinum, Pelplin 2019 (odtąd: ESI). Tłumaczenie przytaczanych fragmentów Ecclesiae Sponsae Imago pochodzi od autora.

${ }^{28}$ Wypada podkreślić, że w aspekcie formalnym - zgodnie ze swoją naturą prawną (kan. 34) - instrukcja jest rozporządzeniem administracyjnym. Nie stanowi ona nowego prawa, lecz jedynie zaleca przestrzeganie prawa już obowiązującego. W tym też znaczeniu należy rozumieć postanowienia zawarte w powyższej instrukcji.

${ }^{29}$ B. Zubert, Komentarz do Kodeksu Prawa Kanonicznego z 1983 r., t. 2 cz. III, księga II. Lud Boży, część III. Instytuty życia konsekrowanego i stowarzyszenia życia apostolskiego, Redakcja Wydawnictw KUL, Lublin 1990, s. 41.

${ }^{30}$ Por. J. Beyer, Le forme individuali di vita consacrata, Quaderni di Diritto Ecclesiale 5 (1992), nr 2, s. 132.
} 
31 maja 1970 r. Na płaszczyźnie diecezjalnej podstawę tę stanowi statut lub regulamin zatwierdzony przez biskupa diecezjalnego.

Należy zauważyć, że KPK 1983 regulując kwestię dziewic konsekrowanych podaje przepisy bardzo ogólne, ramowe. Wskazane jest jedynie kanoniczne kryterium Ordo virginum, którym jest: zobowiązanie się do praktyki rad ewangelicznych wobec biskupa diecezjalnego, który także kieruje ich realizacją. Bardziej szczegółowe normy podaje instrukcja Ecclesiae Sponsae imago, natomiast bardziej konkretne normy, dostosowane do warunków miejscowych, powinny być regulowane w statutach ${ }^{31}$.

Definicję dziewic konsekrowanych zawiera kan. $604 \$ 1$, zaliczając do tej formy życia osoby „Bogu poświęcone przez biskupa diecezjalnego według zatwierdzonego obrzędu liturgicznego, (...) zaślubione mistycznie Chrystusowi, Synowi Bożemu, i przeznaczone na służbę Kościołowi”. Jest to kanon opisowy, mówiący o tym, że Ordo virginum jest podobne do form życia konsekrowanego, które według KPK obejmuje instytuty życia konsekrowanego (instytuty zakonne i świeckie) oraz stowarzyszenia życia apostolskiego. Nie jest jednak częścią instytutów życia konsekrowanego, ale jest częścią życia konsekrowanego. Jest to ordo (stan) w znaczeniu grupy, a nie zakon, instytut czy zgromadzenie ${ }^{32}$.

W przytoczonej definicji kanonicznej z kan. $604 \$ 1$ można wyróżnić następujące elementy. Prawodawca mówi o „mistycznych zaślubinach z Chrystusem", co oznacza praktykę jednej rady ewangelicznej czystości. Celem życia dziewic jest dokładniejsze naśladowanie Chrystusa poprzez zamiar życia w czystości ${ }^{33}$, który, nie będąc ślubem zakonnym, jest jednak publiczny. Kanon nie mówi o ubóstwie i posłuszeństwie, chociaż w sequela Christi te rady ewangeliczne

\footnotetext{
${ }^{31}$ Zob. A. Skorupa, Teologiczne i prawne podstawy nowych form życia konsekrowanego, w: Życie konsekrowane znakiem wiarygodności Kościoła, red. A. Dudek, R. Kantor, Kraków 2017, s. 183.

${ }^{32}$ Por. G. Ortega Gavara, La configuracion juridica del ordo virginum, Facultad de Derecho Canonico, Madrid 2018, s. 15.

${ }^{33}$ „Dziewice poświecone Bogu z natchnienia Ducha Świętego ślubują czystość, aby bardziej kochać Chrystusa i lepiej służyć bliźnim”. OCV, Praenotanda, nr 2.
} 
są zawarte. Odnośnie do ubóstwa, dziewice mają prowadzić życie skromne, dalekie od luksusu i ostentacji, ale nie niedbałe. Dlatego dziewica konsekrowana nie powinna mylić ewangelicznego ubóstwa (które cechuje życie zakonnic) z zewnętrznym pauperyzmem, który nie zawsze oznacza oderwanie się od rzeczy materialnych. Nie ma bowiem autentycznego zewnętrznego ubóstwa bez wewnętrznego oderwania od spraw materialnych. Jeśli chodzi o posłuszeństwo, dziewice konsekrowane zależą od biskupa diecezji, w której zostały konsekrowane, który może poprosić je o jakąś posługę apostolską, i któremu winny zdawać relację $\mathrm{z}$ ich regula vitae ${ }^{34}$.

Dziewice konsekrowane zostają zaślubione mistycznie Chrystusowi. Owe zaślubiny stanowią najbardziej nieodłączną i istotną cechę tej formy życia, ponieważ dziewice prawdziwie są oblubienicami ${ }^{35}$, dlatego po przyjęciu konsekracji otrzymują dwa charakterystyczne znaki małżeństwa: pierścień i welon ${ }^{36}$. Wypada zauważyć, że KPK wyraźnie stwierdza, że przez zatwierdzony obrzęd liturgiczny dziewica zostaje mistycznie poślubiona przez Chrystusa Syna Bożego. Wynika z tego jasno, że jednym z głównych skutków konsekracji dziewic jest

\footnotetext{
${ }^{34}$ Por. G. Ortega Gavara, La configuracion juridica del ordo virginum, s. 15; por. R. McDermott, Commentary on canon 604, w: New Commentary on the Code of Canon Law, edited by J. Beal, Paulist Press, New York 2000, s. 769. Podobnie jak w przypadku pustelników, konsekracja dziewic jest konsekracją ad personam, zarówno indywidualną, jak i diecezjalną: dziewice konsekrowane nie są zależne od żadnego instytutu, a ich bezpośrednim przełożonym (wobec którego nie są jednak związane ślubem posłuszeństwa) jest biskup diecezjalny. Por. I. Turina, Vers un catholicisme " exemplaire»?, Archives de sciences sociales des religions 133 (2006), s. 120 .

${ }^{35}$ Por. I. Turina, Vers un catholicisme « exemplaire»?, s. 120. Należy zauważyć, że słowo „sponsa”, oznaczające oblubienicę Chrystusa, należy do słownictwa mistycznego. W kan. 604 używa się właśnie słowa mistyka: „zaślubione mistycznie Chrystusowi”. M. Dion, La consécration des vierges. Implications juridiques, s. 130.

${ }^{36} \mathrm{OCV}$ przewiduje przekazanie welonu i obrączki zgodnie z lokalnym zwyczajem: „Oprócz tego, co jest potrzebne do odprawienia Mszy świętej należy przygotować: (...) welony, obrączki oraz inne oznaki konsekracji, które według miejscowych przepisów albo zwyczajów należy wręczyć dziewicom”. OCV, Caput I, nr 8 b; zob. por. S. ReCCHI, L'ordine delle vergini, s. 143.
} 
ukonstytuowanie się poświęconej kobiety w stanie podobnym do stanu kobiety zamężnej, i że w konsekwencji z obrzędu konsekracji dziewic wynika fakt, że kolejne naturalne małżeństwo (z określonym mężczyzną) nie jest dozwolone ${ }^{37}$.

Zobowiązanie do przestrzegania czystości dziewica składa wobec biskupa diecezjalnego według uroczystego obrzędu liturgicznego, który wyraża też doniosłość tej formy poświęcenia się Bogu. To nie dziewice same z siebie oddają się w sposób szczególny Chrystusowi, lecz są poświęcane (konsekrowane) Bogu przez biskupa diecezjalnego, który może delegować do szafarstwa tego obrzędu innego biskupa $^{38}$ (pomocniczego lub tytularnego), przez co ukazuje się jeszcze

${ }^{37}$ „Przez biskupa diecezjalnego (...) zostają zaślubione mistycznie Chrystusowi, Synowi Bożemu”. Kan. $604 \$ 1$; por. M. Dion, La consécration des vierges. Implications juridiques, s. 123. Kto jest nazywany biskupem diecezjalnym? KPK z 1983 r. stanowi: w kan. $134 \$ 3$ prawodawca mówi, że pod imieniem biskupa diecezjalnego należy rozumieć samego biskupa diecezjalnego (kan. $381 \S 1$ ) oraz tych, którzy są z nim w prawie zrównani (kan. 381-\$2, 370 i 371). O ile nie otrzymali specjalnego zlecenia, wikariusz generalny i wikariusz biskupi nie podpadają pod miano biskupa diecezjalnego (kan. $134 \$ 3$ ). M. Dion, La consécration des vierges. Implications juridiques, s. 185.

${ }^{38}$ „Szafarzem obrzędu konsekracji dziewic jest biskup ordynariusz miejsca. Inny biskup może przewodniczyć obrzędowi za zgodą biskupa diecezjalnego”. OCV, Praenotanda, nr 6 wymienia tylko biskupa ordynariusza miejsca: „Minister ritus consecrationis virginum est Episcopus Ordinarius loci”. Polski przekład dodaje, że „Inny biskup może przewodniczyć obrzędowi za zgodą biskupa diecezjalnego”. Pontyfikał Rzymski, Obrzędy konsekracji dziewic, Wydanie wzorcowe, nr 6, Wydawnictwo Księgarnia św. Jacka, Katowice 2001. Natomiast w KPK wymienia się tylko „biskupa diecezjalnego” (Episcopo dioecesano). Kan. $604 \$ 1$. Zob. zapis dyskusji konsultorów odnośnie do kwestii: ordynariusz miejsca, czy biskup diecezjalny szafarzem konsekracji dziewic: Pontificia Commissio Codici IURIs Canonici Recognoscendo, Communicationes 11 (1979), s. 331. Należy skonstatować, że w kolejnym wydaniu typicznym (Editio Typica altera) winno się, idąc za Kodeksem umieszczać termin „biskup diecezjalny”, a nie „Episcopus Ordinarius loci”. Może dziwić, że przywołane wydanie polskie, używa niejasnego terminu „biskup ordynariusz miejsca”, mimo że zostało opublikowane wiele lat po poromulgacji KPK z 1983 r. W świetle kan. 2 należy stwierdzić, że przepisy liturgiczne zawarte w Kodeksie mają charakter nadrzędny w stosunku do pozakodeksowych przepisów liturgicznych i utraciły swoją moc, jeśli są sprzeczne z przepisami Kodeksu. 
jedna istotna cecha charakterystyczna tego stanu, mianowicie diecezjalność, a więc więź duchowa i kanoniczna z Kościołem lokalnym i z biskupem. Dziewice konsekrowane poprzez obrzęd konsekracji, celebrowany podczas uroczystości publicznej, najlepiej w katedrze, zostają ściśle związanie $\mathrm{z}$ diecezją ${ }^{39}$. Jan Paweł II w adhortacji Vita consecrata przypomina, że „Dziewice konsekrowane przez Biskupa łączą się szczególną więzią z Kościołem lokalnym, któremu służą z poświęceniem, chociaż pozostają w świecie" ${ }^{40}$, jak również „dziewice konsekrowane, żyjące w świecie, urzeczywistniają swoją konsekrację przez szczególną więź komunii z Kościołem partykularnym i powszechnym" ${ }^{41}$.

Należy zauważyć, że to nie dziewice konsekrują się, ale one są konsekrowane. Kobieta podejmując publicznie zamiar (postanowienie) czystości, który wcześniej podjęła w formie prywatnej, otrzymuje od Kościoła uznanie tego stanu poprzez publiczną konsekrację, co czyni ją nową (świętą) osobą poprzez zatwierdzony przez Kościół obrzęd liturgiczny. Zawsze w Kościele istniały dziewice, niektóre były konsekrowane poprzez określony obrzęd, a inne zwyczajnie były poświęcone Chrystusowi nieformalnie, poprzez śluby prywatne. Tylko jednak te pierwsze posiadają status dziewicy konsekrowanej ${ }^{42}$.

${ }^{39}$ „Ponieważ dziewice żyjące w świecie zwykle służą dziełom diecezjalnym i biskup dopuszcza je do konsekracji, obrzęd powinien się odbyć w kościele katedralnym, chyba że okoliczności i zwyczaje miejscowe przemawiają przeciw temu”. OCV, Caput I, nr 3; „Cechą charakterystyczną tej formy życia jest włączenie kobiet konsekrowanych do Kościoła partykularnego, a więc w specyficzny kontekst kulturowy i społeczny”. ESI, nr 37; por. G. Ortega GaVARA, La configuracion juridica del ordo virginum, s. 16.

${ }^{40}$ IoAnnes Paulus P.P. II, Adhortatio Apostolica Vita consecrata (25 martii 1996), „Acta Apostolicae Sedis” 88 (1996), nr 7, s. 377-486; tekst polski: JAN PAwEŁ II, Adhortacja Apostolska Vita Consecrata, Wydawnictwo TUM, Wrocław 1999 (odtąd: $\mathrm{VC})$.

${ }^{41} \mathrm{VC}, \mathrm{nr} 42$.

${ }^{42}$ Por. G. Ortega Gavara, La instrucción «Ecclesiae sponsae imago» sobre el «ordo virginum». El estado de virginidad en el siglo XXI, Estudios eclesiásticos 94 (2019), nr 371, s. 843 . 
Następnie Kodeks podkreśla, że jest to „stan” (ordo), tzn. pewien zorganizowany (stabilis vivendi forma), w przeciwieństwie do życia pustelniczego, stabilny sposób życia (bez takiej stabilności nie można by mówić o prawdziwej konsekracji), którego ani w przeszłości, ani obecnie nie określano tym terminem ${ }^{43}$, a do którego środkiem dostępu jest obrzęd konsekracji, należycie dokonany przez biskupa diecezjalnego. Należy podkreślić, że kobieta, która przyjęła konsekrację, jest kobietą świecką. Jednakże konsekracja dziewic sytuuje ją w ramach formy życia oficjalnie uznanej w Kościele: w stanie dziewic $^{44}$. Prawodawca używając dla tej formy życia konsekrowanego terminu „stan” (ordo) wyraża szczególny szacunek i uznania dla tego rodzaju życia konsekrowanego w Kościele, a co znajduje głębokie uzasadnienie w celu, jaki przyświeca tym, którzy podejmują tę formę życia w Kościele ${ }^{45}$.

Silvia Recchi zwraca uwagę, iż fakt, że konsekrowana dziewica jest formalnie zobowiązana do „profesji” tylko jednej z trzech rad ewangelicznych, skłonił niektórych do konstatacji, że dziewice konsekrowane nie w pełni przynależą do stanu życia konsekrowanego, który zawsze wiąże się ze składaniem profesji trzech rad ewangelicznych. Wymieniona autorka stwierdza niesłuszność powyższych wniosków, gdyż o ile specyfika dziewictwa konsekrowanego wyraża się przede

${ }^{43}$ Por. B. Zubert, Komentarz do Kodeksu Prawa Kanonicznego z 1983 r., s. 42. Podczas prac nad odnową Kodeksu odnoszących się do dziewic konsekrowanych jeden z konsultorów był zdania, że lepiej jest użyć w przyszłym kanonie terminu „ordo” niż „status”, gdyż mimo konsekracji, dziewice nie należą do stanu życia konsekrowanego przez profesję rad ewangelicznych: „Un Consultore dice che è meglio " ordo » che "status », perché, nonostante la consacrazione, le vergini non appartengono allo stato di vita consacrata per la professione dei consigli evangelici". Pontificia Commissio Codici Iuris Canonici Recognoscendo, Communicationes 11 (1979), s. 331.

${ }^{44}$ M. Dion, La consécration des vierges. Implications juridiques, Introduction, s. X; por. S. Recchi, L'ordine delle vergini, s. 142.

${ }^{45}$ Por. A. Chra pkowski, J. Krzywda, Komentarz do kan. 604, w: Komentarz do Kodeksu Prawa Kanonicznego. Tom II/2. Część III. Instytuty życia konsekrowanego i stowarzyszenia życia apostolskiego, red. J. Krukowski, Wydawnictwo Pallottinum, Poznań 2006, s. 37. 
wszystkim w formalnym zobowiązaniu do doskonałej czystości, o tyle głębszy sens dziewictwa konsekrowanego nie ogranicza się do czystości i powściągliwości. Prawdziwie ewangeliczne dziewictwo suponuje z konieczności pomoc ubogim, wstrzemięźliwość w życiu, posłuszeństwo jako poddanie się woli Bożej, podobnie jak zależność od biskupa i oddanie się Kościołowi. Całkowite poświęcenie dziewicy jest w rzeczywistości następstwem naśladowania Oblubieńca. Konsultorzy w czasie prac nad rewizją Kodeksu Prawa Kanonicznego wyraźnie żądali, aby kanon dotyczący dziewic konsekrowanych odwoływał się do sequela Christi („pójść za Chrystusem” czy „naśladować Go”) właśnie dlatego, że w ten sposób implikowane są również ubóstwo i posłuszeństwo, jako wyraźnie złączone z czystością ${ }^{46}$.

Z kolei w analizowanej definicji chodzi o „dziewice” w sensie ścisłym, tj. nie mogą to być ani wdowy, ani kobiety, które publicznie czy tajnie żyły w sposób przeciwny czystości, a ich wiek, roztropność i obyczaje powinny stanowić gwarancję wytrwania w powziętym zamiarze. Według Ordo Consecrations Virginum „Do konsekracji można dopuszczać dziewice żyjące w świecie, które: a) nigdy nie zawierały małżeństwa ani nie żyły publicznie, czyli jawnie, w stanie przeciwnym czystości; b) według ogólnej opinii przez swój wiek, roztropność i obyczaje dają rękojmie, że wytrwają w życiu czystym oraz poświęconym służbie Kościołowi i bliźnim"47. Instrukcja Ecclesiae

\footnotetext{
${ }^{46}$ S. ReCCHI, L'ordine delle vergini, s. 144-145. „Un nono Consultore preferisce che si dica «sanctum propositum Christum pressius sequendi», perché così anche la povertà e la obbedienza vengono sottintese come unite implicitamente alla castità". Pontificia Commissio Codici Iuris Canonici Recognoscendo, Communicationes 11 (1979), s. 333.

${ }^{47} \mathrm{OCV}$, Praenotanda, nr $5 \mathrm{ab}$. OCV ma walor ustawy pozakodeksowej, więc należy go uwzględniać w m. in. w kwestii wymogów kandydatek na dziewice konsekrowane. Por. G. Ortega Gavara, La configuracion juridica del ordo virginum, s. 16. „Dopuszczenie do konsekracji wymaga, aby ze względu na swój wiek, dojrzałość ludzką i duchową oraz szacunek, jakim cieszy się we wspólnocie chrześcijańskiej, do której została włączona, kandydatka wykazała, że jest zdolna do odpowiedzialnego przyjęcia zobowiązań wynikających z konsekracji. Wymaga się również, aby osoba nigdy nie zawierała małżeństwa, ani nie żyła publicznie, czyli jawnie, w stanie przeciwnym czystości”. ESI, nr 84.
} 
sponsae imago podaje ponadto konieczność odpowiedniego poziomu życia duchowego i stosownej dojrzałości ludzkiej ${ }^{48}$.

Od średniowiecza do Soboru Watykańskiego II słowo „czystość” było synonimem całkowitej abstynencji, czyli powściągliwości seksualnej. Jeśli chodzi o tych, których czystość ograniczała się tylko do wyrzeczenia się zabronionych przyjemności, to ich czystość była uważana za niedoskonałą (małżonkowie). Ojcowie Soboru Watykańskiego II widzieli tę sprawę inaczej: Sobór nie zachował rozróżnienia między czystością doskonałą a niedoskonałą, a także przypomniał, że tym, co nadaje specyficzny charakter czystości, jest sytuacja egzystencjalna chrześcijanina. W ten sposób teksty soborowe mówią o czystości zaręczonych, małżonków, zakonników, kapłanów, diakonów i seminarzystów. Należy więc skonstatować, że istnieje jedynie czystość małżeńska i pozamałżeńska ${ }^{49}$. Zmiana perspektywy odnośnie do pojmowania czystości seksualnej, dokonana przez Sobór Watykański II, pozwala głębiej spojrzeć na czystość i zrozumieć, że do stanu dziewic konsekrowanych nie mogą jedynie wstępować kobiety, które zawierały małżeństwa (konsekrowani wdowy i wdowcy stanowią osobny stan w Kościele), są rozwiedzione, żyły publicznie, czyli jawnie, w stanie przeciwnym czystości ${ }^{50}$ oraz, które według ogólnej opinii przez swój wiek, roztropność i obyczaje nie dają rękojmi, że wytrwają w życiu czystym ${ }^{51}$. Potwierdza to Ecclesiae Sponsae Imago z 2018, gdzie zapisano: „Musimy pamiętać, że danie świadectwa

\footnotetext{
${ }^{48}$ ESI, nr 86-87.

${ }^{49}$ Por. M. Dion, La consécration des vierges. Implications juridiques, s. 19.

${ }^{50}$ Do kategorii tej należą $\mathrm{m}$. in. nawrócone prostytutki, osoby, które żyły w związkach niesakramentalnych lub takie, które publicznie mówiły o swoim wcześniejszym nieuporządkowanym życiu seksualnym, np. dając świadectwo nawrócenia. Dla kobiet, które się nawróciły i pragną żyć w czystości, rozwiązaniem jest prywatny ślub czystości złożony na ręce spowiednika. Trzeba dodać, że powołanie do stanu dziewic może mieć osoba, która doświadczyła przemocy seksualnej. Wprawdzie nie ma już fizycznego znaku dziewictwa, ale w jej przypadku do aktywności seksualnej doszło wbrew jej woli. Stąd zamknięcie przed nią drogi do konsekracji nie byłoby słuszne.

${ }^{51}$ Por. OCV, Praenotanda, nr 5 ab; por. ESI, nr 84.
} 
o dziewiczej, oblubieńczej i płodnej miłości Kościoła do Chrystusa nie poddaje się redukcji do czysto fizycznego symbolu integralności ciała. Jakkolwiek zachowanie całkowitej wstrzemięźliwości cielesnej lub praktykowanie czystości (seksualnej) we wzorcowy sposób są istotnym elementem przy rozeznaniu tego powołania, to nie stanowią jednak warunków, bez wypełnienia których zgoda na konsekrację nie jest możliwa"52. Tak więc prawodawca kościelny w dopuszczaniu do stanu dziewic konsekrowanych bierze pod uwagę kryteria zewnętrzne i publiczne, abstrahując od kryteriów fizycznych ${ }^{53}$.

„Święty zamiar” - to dalszy element analizowanej definicji. Zdaniem D.J. Andresa ${ }^{54}$, według tradycji sięgającej czasów patrystycznych, jest to sposób zobowiązania zbliżony do ślubu, poprzez który obierają one życie w takim stanie i poświęcają się Bogu.

Zobowiązanie, które dziewica konsekrowana winna przyjąć, wynika ze „świętego zamiaru” (sanctum propositum emitientes Christum pressius sequendi...), który deklaruje ona podczas obrzędu konsekracji. Formalnie „święty zamiar” jest publiczną i uroczystą deklaracją własnej woli wobec Boga i Kościoła, deklaracją stabilności (stałości) życia, doskonałej czystości dla Królestwa, naśladowania Chrystusa. W sensie ściśle prawnym nie jest to „ślub”, choć ma tę samą rangę. „Święty zamiar” należy bowiem uważać za „świętą więź", której Kościół wymaga dla każdej formy życia konsekrowanego. „Święty

\footnotetext{
${ }^{52}$ ESI, nr 88; por. nr 16.

${ }^{53}$ Dziewictwo jest tradycyjnym terminem używanym na oznaczenie powstrzymywania się od wszelkiej aktywności seksualnej. Kojarzy się przede wszystkim ze wstrzemięźliwością i mimo wszystko posiada wydźwięk kobiecy. Pomimo wypowiedzi niektórych pisarzy duchowych, używanie słowa „dziewica” w stosunku do mężczyzn okazuje się niezręczne i sztuczne. Ponadto termin „dziewictwo” podkreśla kwestię integralności fizycznej, której Nowy Testament nie uważa za istotną. Tradycyjnie mówi się też o doskonałej czystości. Termin ten nie jest również pozbawiony wad, ponieważ może sprawiać wrażenie, że małżeństwo nie jest naprawdę czyste, że może być postrzegane, jako posiadające pierwotną wadę (defekt). Por. L. LEGRAND, The Biblical Doctrine of Virqinity, London, Publisher Geoffrey Chapman Ltd., 1963, s. 167; por. M. Dion, La consécration des vierges. Implications juridiques, s. 5.

${ }^{54}$ D. Andres, Il diritto dei religiosi. Commento esegetico al Codice, Ediurcla, Roma 1984, s. 38.
} 
zamiar" pociąga za sobą obowiązek celibatu i wieczystej czystości ${ }^{55}$ (poważna niewierność wobec tego obowiązku oznaczałaby świętokradztwo). Konsekracja dziewic zawiera więc w sobie pełną treść wieczystego, publicznego ślubu czystości. Ewentualna dyspensa (analogicznie do tego, co przewidziano w kan. 686) należy do biskupa diecezjalnego. Instrukcja Ecclesiae Sponsae Imago tak rozstrzyga tę kwestię: „Jeśli kobieta konsekrowana, z bardzo poważnych powodów, ocenianych przed Panem po starannym rozeznaniu, pragnie zwolnienia z obowiązków wynikających z konsekracji, zwróci się do swojego biskupa diecezjalnego z pisemną prośbą. Biskup nie może zaniedbać zapewnienia jej odpowiedniej pomocy i odpowiedniego czasu na rozeznanie. Udzieli dyspensy dopiero po dogłębnej analizie powodów jej prośby" ${ }^{56}$. Jednakże mogą zaistnieć przyczyny, które domagają się wydalenia kobiety $\mathrm{z}$ ordo virginum. Instrukcja Ecclesiae Sponsae Imago przewiduje i takie przypadki i wyjaśnia, jak następuje: „Jeśli kobieta konsekrowana notorycznie odstąpiła od wiary katolickiej lub zawarła małżeństwo, nawet cywilne, biskup zbierze dowody i ogłosi jej usunięcie z Ordo virginum w sposób przewidziany w prawie. W przypadku, gdy kobieta konsekrowana zostanie oskarżona o bardzo poważne przestępstwa lub uchybienia zewnętrzne przeciw zobowiązaniom wynikającym z konsekracji, które można jej przypisać, które wywołują zgorszenie wśród ludu Bożego, biskup rozpocznie procedurę dymisji. Poinformuje zatem kobietę o zarzutach i zebranych dowodach, dając jej możliwość obrony. Jeśli biskup uzna, że jej obrona jest niewystarczająca i nie ma innego sposobu na jej poprawę, przywrócenie sprawiedliwości i naprawienie zgorszenia, wydali ją z Ordo virginum. W dekrecie o wydaleniu należy przynajmniej sumarycznie określać powody decyzji. Dekret wydalający nie

\footnotetext{
${ }^{55}$ „W obrzędzie konsekrowani wyrażają sanctum propositum (święte postanowienie). Jest to mocne i ostateczne postanowienie wytrwania przez całe życie w doskonałej czystości, w służbie Bogu i Kościołowi, naśladując Chrystusa zgodnie z Ewangelią, aby dać światu żywe świadectwo miłości i być wyraźnym znakiem przyszłego Królestwa”. ESI, nr 19.

${ }^{56}$ ESI, nr 70.
} 
posiada mocy, jeśli nie został potwierdzony przez Stolicę Świętą, której należy przesłać dekret i wszystkie akta. Do ważności, dekret powinien zaznaczyć przysługujące wydalonej prawo, wniesienia w ciągu dziesięciu dni od otrzymania powiadomienia, rekursu do kompetentnej władzy. Rekurs posiada skutek zawieszający.

We wszystkich przypadkach separacji kobiety konsekrowanej od Ordo virginum biskup diecezjalny zadba o to, aby zostało to zapisane w księdze konsekracji. Zarządzi, aby poinformować o tym fakcie inne konsekrowane, osobiście lub przez delegatkę i odpowiedzialnego proboszcza, aby mógł to odnotować w księdze chrztu" ${ }^{57}$. Należy pamiętać, że właściwą dykasterią dla dziewic konsekrowanych jest Kongregacja ds. Instytutów Życia Konsekrowanego i Stowarzyszeń Życia Apostolskiego ${ }^{58}$.

„Święty zamiar” deklarowany podczas konsekracji dziewic nie jest tylko zobowiązaniem wewnętrznym, lecz zewnętrznym i trwałym, złożonym wobec Kościoła. Jednakże według Ordo Consecrations Virginum biskup ustali, w jaki sposób dziewice żyjące w świecie, mają się zobowiązać do życia w dozgonnej czystości ${ }^{59}$. Prawo nie rozstrzyga, czy to ma być ślub, czy przysięga, czy inne jakieś zobowiązanie wyrażone na zewnątrz, decyzję zostawia biskupowi ${ }^{60}$. To

\footnotetext{
${ }^{57}$ ESI, nr 71-73. Kan. 1088. „Nieważnie usiłują zawrzeć małżeństwo ci, którzy są związani wieczystym ślubem publicznym czystości w instytucie zakonnym”. Konsekracja dziewic nie jest przeszkodą zrywająca do małżeństwa, ale bez dyspensy powoduje niegodziwe zawarcie małżeństwa.

${ }^{58}$ „Kompetencji Kongregacji podlegają także eremici, dziewice konsekrowane i ich zrzeszenia oraz pozostałe formy życia konsekrowanego". IoAnnes PAULUS P.P. II, Constitutio Apostolica Pastor Bonus, (28 iulii 1988), art. 110, „Acta Apostolicae Sedis” 80 (1988), s. 841-912, tekst polski: JaN PAwEŁ II, Konstytucja apostolska Pastor bonus o Kurii Rzymskiej, w: Ustrój hierarchiczny Kościoła. Wybór źródeł, red. W. Kacprzyk, M. Sitarz, Lublin: Towarzystwo Naukowe KUL, Lublin 2006, s. 217-257; ESI, nr 7; por. S. RECCHI, L'ordine delle vergini, s. 144.

59 „Do biskupa należy ustalenie sposobu, w jaki dziewice prowadzące życie świeckie mają się zobowiązać do zachowania dziewictwa na zawsze”. Por. OCV, Praenotanda, nr $5 \mathrm{c}$.

${ }^{60}$ J. BAR, Nowy obrzęd konsekracji dziewic, Prawo Kanoniczne 15 (1972), nr 1-2, s. 253.
} 
poświęcenie Bogu ma się dokonać według „,zatwierdzonego obrzędu liturgicznego", czyli Ordo Consecrations Virginum ${ }^{61}$.

Prawodawca wreszcie stanowi, że dziewice konsekrowane zaślubione mistycznie Chrystusowi, Synowi Bożemu, są przeznaczone na służbę Kościołowi ${ }^{62}$. Dziewice poświęcają Bogu swą czystość pod natchnieniem Ducha św. w tym celu, aby bardziej umiłować Chrystusa i swobodniej oddać się na służbę bliźnim. Gdyż dziewice chrześcijańskie, zgodnie ze swoim stanem i otrzymanymi charyzmatami, mają się oddawać pokucie, uczynkom miłosierdzia, działalności apostolskiej i modlitwie. Zaleca się im usilnie, aby dla lepszego spełnienia obowiązku modlitwy odmawiały codziennie Liturgię Godzin, zwłaszcza Jutrznię i Nieszpory ${ }^{63}$. Konkretniej jednak, to biskup diecezjalny ustala w jaki sposób, zobowiązują się one do służby Kościołowi poprzez pokutę, modlitwę, uczynki miłosierdzia i działalność apostolską ${ }^{64}$. Stąd według Instrukcji Rozpoczać na nowo od Chrystusa obecność w Kościele lokalnym dziewic konsekrowanych wymaga

${ }^{61}$ Por. B. Zubert, Komentarz do Kodeksu Prawa Kanonicznego z 1983 r., s. 42.

${ }^{62}$ Por. kan. $604 \$ 1$.

63 „Dziewice konsekrowane w świecie, ofiarują Bogu radości i cierpienia, dążenia i prośby wszystkich ludzi i kontemplują oblicze Chrystusa, które rozpoznają w obliczu braci, w wydarzeniach historii, w apostolstwie i w codziennej pracy". Congregazione per gli Istituti di Vita Consacrata e le Società di Vita Apostolica, Istruzione Ripartire da Cristo: un rinnovato impegno della vita consacrata nel terzo millennio (19 maggio 2002), nr 25, Libreria Editrice Vaticana, Città del Vaticano 2002, tekst polski: Kongregacja Instytutów Życia KonsekroWAnego i Stowarzyszeń Życia Apostolskiego, Instrukcja Rozpocząć na nowo od Chrystusa, Wydawnictwo Pallottinum, Poznań 2002, (odtąd: RdC); por. ESI, nr 43. „Stan dziewic obejmuje kobiety żyjące w świecie (...), które poświęcają się modlitwie, pokucie, służbie braciom i pracy apostolskiej, stosownie do ich stanu i odpowiednich charyzmatów ofiarowanych każdej z nich". Catechismo della Chiesa Cattolica, nr 924, Città del Vaticano 1992, tłum. polskie: Katechizm Kościoła Katolickiego, Wydawnictwo Pallottinum, Poznań 1994.

${ }^{64}$ OCV, Praenotanda, nr 2. Dlatego biskup diecezjalny powinien zatwierdzić statut, czy regulamin dziewic konsekrowanych w swojej diecezji. Niektóre konferencje episkopatów wydały dyrektoria o dziewicach konsekrowanych np. we Włoszech, czy Argentynie 
specjalnej uwagi ze strony biskupów ${ }^{65}$, a autorzy Dyrektorium o pasterskiej postudze biskupów „Apostolorum Successores” podkreślają, że „specjalną troską biskup winien ogarniać stan dziewic, które zostały konsekrowane Bogu przez jego ręce i jako osoby poświęcone dla służby Kościołowi są powierzone jego pasterskiej pieczy"66.

Prawodawca w Dyrektorium o pasterskiej posłudze biskupów „Apostolorum Successores" odnosi się do zaangażowania dziewic konsekrowanych w życie diecezji. Przypomina, że biskup ma czuwać, „aby dla dziewic konsekrowanych znalazła się odpowiednia przestrzeń uczestnictwa w rozmaitych instancjach diecezjalnych, np. w diecezjalnych i parafialnych radach duszpasterskich (tam gdzie istnieją), w różnych komisjach i delegacjach diecezjalnych, w kierownictwie różnych inicjatyw apostolskich i edukacyjnych diecezji, a także aby uczestniczyły one w podejmowaniu decyzji - przede wszystkim tych, które ich dotyczą, aby w ten sposób mogły ofiarować Ludowi Bożemu swą szczególną wrażliwość i zapał misyjny, doświadczenie i kompetencje" 67 .

\section{Prawo dziewic konsekrowanych do zrzeszania się}

Stosownie do kan. $604 \$ 2$ dziewice mają prawo do zrzeszania się w celu wierniejszego wypełnienia swoich zamierzeń oraz owocniejszej służby Kościołowi ${ }^{68}$. W. Zubert ${ }^{69}$ przypomina, że przytoczona norma wywołała ożywioną dyskusję wśród konsultorów. Słusznie poniekąd zwracano uwagę, iż może ona sugerować powstanie nowego insty-

\footnotetext{
${ }^{65}$ Por. RdC, nr 19.

${ }^{66}$ Congregaticio pro Episcopis, Direttorio per il ministero pastorale dei vescovi (22 febbraio 2004), nr 104, Editore: Libreria Editrice Vaticana, Città del Vaticano 2004, tekst polski: KongregaCja Do spRAw Biskupów, Dyrektorium o pasterskiej posłudze biskupów „Apostolorum Successores”, Wydawnictwo „Jedność”, Kielce 2005, (odtąd: AS); por. ESI, nr 7.

${ }^{67} \mathrm{AS}, \mathrm{nr} 104$.

${ }^{68}$ „Dziewice mogą się zrzeszać dla wierniejszego wypełnienia swojego zamiaru oraz dla służby Kościołowi, odpowiadającej ich własnemu stanowi i wykonywanej przy wzajemnej pomocy”. Kan. $604 \$ 2$.

${ }^{69}$ B. Zubert, Komentarz do Kodeksu Prawa Kanonicznego z 1983 r., s. 43.
} 
tutu życia konsekrowanego, co nie było celem prawodawcy. Z kolei kwestionowano jej potrzebę ze względu na przysługujące wszystkim wiernym prawo do „swobodnego zakładania stowarzyszeń”70. Ostatecznie jednak większością głosów zadecydowano o wprowadzeniu $\$ 2$ do kan. 604, bliżej precyzując cel tworzenia takich zrzeszeńn ${ }^{71}$. Jeżeli się więc je założy, należy zachować normy wspólne dla stowarzyszeń wiernych $^{72}$, naturalnie $z$ odpowiednimi modyfikacjami; nie jest także wykluczone stowarzyszenie w formie trzeciego zakonu, o ile spełni się wymagania kan. 303.

Prawodawca kodeksowy przypomina, że stan dziewic nie jest częścią instytutów życia konsekrowanego (jest stanem konsekrowanym, autonomicznym), ponieważ dziewice wyrażają jedynie zamiar czystości, nie składając profesji rad ewangelicznych, nawet jeśli ów zamiar obejmuje implicite życie dalekie od luksusu i ostentacji oraz życie w posłuszeństwie, wywodzącym się z ich więzi z biskupem diecezji, w której zostały konsekrowane. Trzeba powiedzieć, że podobnie życie wspólne nie jest elementem ich egzystencji (jest braterskie, ponieważ mają to samo powołanie), chociaż mogą się zrzeszać lub korzystać ze wspólnego domu, ale nie w formie domu zakonnego o strukturze hierarchicznej, ale jako siostry na równych prawach, które żyją razem z własnej woli, tymczasowo lub na stałe ${ }^{73}$. Stąd instrukcja Ecclesiae Sponsae Imago pod numerem 66 zawiera następujący passus: „Dziewice konsekrowane, które tego pragną, mogą

\footnotetext{
${ }^{70}$ Kan. 215. Stowarzyszenia dziewic konsekrowanych nie są instytutami życia konsekrowanego ani pośrednimi etapami prowadzącymi uznania je za tego rodzaju. Prawo do zrzeszania się zapewniają im kan. 298-329 KPK, formalizując naturalne prawo wszystkich wiernych do zrzeszania się. Dziewica konsekrowana należy do „Ordo” bez konieczności formacji w stowarzyszeniu. Nie wstępuje ona do zakonu ani czegoś podobnego.

${ }^{71}$ Zob. dyskusję konsultorów o zrzeszaniu się dziewic konsekrowanych: PonTIficia Commissio Codici Iuris Canonici Recognoscendo, Communicationes 11 (1979), s. 331-334.

${ }^{72}$ Kan. 298-311.

${ }^{73}$ Por. G. Ortega Gavara, La instrucción «Ecclesiae sponsae imago» sobre el «ordo virginum», s. 843.
} 
dobrowolnie zdecydować się zamieszkać w tym samym domu. Ta opcja, wybrana odpowiedzialnie w celu wzajemnej pomocy, dzielenia życia na poziomie duchowym, duszpasterskim lub finansowym, wyraża wolną decyzję każdej z dziewic konsekrowanych. Nie wypływa to bezpośrednio z konsekracji ani z przynależności do stowarzyszenia, chyba że jego statuty przewidują życie wspólne jako element konstytutywny samego stowarzyszenia”.

Kobiety konsekrowane mogą zrzeszać się w stowarzyszeniach i zwracać się do władz kościelnych o kanoniczne uznanie ich statutów. Stowarzyszenia dziewic mogą być diecezjalne, krajowe, a w danym kraju lub diecezji może być nawet więcej niż jedno stowarzyszenie. W przypadku stowarzyszeń erygowanych na szczeblu krajowym, zatwierdzenie ich i ich statutów należy do kompetencji Konferencji Episkopatu. Zrzeszanie się dziewic w stowarzyszeniach nie jest obowiązkowe, ponieważ zazwyczaj mieszkają one same lub z własnymi rodzinami, ale jest możliwością, która nie oznacza, że stowarzyszenia mają cechy charakterystyczne dla życia wspólnoty zakonnej. Zresztą, między dziewicami a biskupem nie ma przełożonych, ani innej władzy pośredniej. Dziewice konsekrowane zgodnie z kan. 604 KPK nie mają żadnych przełożonych, dyrektorów i nie są zobowiązane do posłuszeństwa żadnemu z prezesów stowarzyszenia. Stowarzyszenia dziewic nie mają wspólnoty dóbr. Zgodnie z instrukcją Ecclesiae Sponsae Imago „Aby wierniej wypełniać swoje propositum i udzielać sobie wzajemnej pomocy w pełnieniu posługi Kościołowi w sposób odpowiadający ich stanowi, kobiety konsekrowane mogą zakładać stowarzyszenia i prosić kompetentną władzę kościelną o kanoniczne uznanie statutu i ewentualnie o zatwierdzenie stowarzyszenia"74. Ważne jest przypomnienie zawarte w cytowanej instrukcji: „Założenie stowarzyszenia lub przystąpienie do stowarzyszenia już istniejącego jest wyłącznie dobrowolnym i wolnym wyborem każdej konsekrowanej dziewicy, która zdecyduje się przyjąć

\footnotetext{
${ }^{74}$ ESI, nr 65.
} 
jego cele i statut. Odejście dziewicy konsekrowanej ze stowarzyszenia nie wpływa negatywnie na jej przynależność do Ordo virginum"75.

Stowarzyszenia, według KPK ${ }^{76}$, mogą być prywatne lub publiczne (w przypadku dziewic wydaje się, że publiczne bardziej odpowiadają ich więzi z diecezją) z osobowością prawną, erygowane dekretem kompetentnej władzy po upewnieniu się, że są pożyteczne i mają środki do osiągnięcia swoich celów. W przypadku dziewic chodzi o to, aby stowarzyszone z większą wiernością wypełniały cel swojej konsekracji i lepiej służyły Kościołowi poprzez promowanie kultu, dzieł apostolskich, prowadzenie działalności charytatywnej i okazywanie miłości poprzez wzajemną pomoc ${ }^{77}$.

G. Ortega Gavara słusznie zauważa, że konstytuowanie stowarzyszeń wiernych przez dziewice konsekrowane nie było, jak dotąd, najczęstszą praktyką, ponieważ stowarzyszenie będzie musiało mieć swoją strukturę: zarząd, dyrektora i statut, co wymaga wielu zabiegów organizacyjnych i fiansowych. Co innego, jeśli osobiście (indywidualnie) należą one do już istniejącego stowarzyszenia wiernych, co jest łatwiejsze ${ }^{78}$.

Stowarzyszenia dziewic mogą być zakładane na szczeblu diecezjalnym lub krajowym, a dziewica może należeć do jednego lub kilku stowarzyszeń; normy lub statuty, które nimi rządzą, muszą być zatwierdzone przez biskupa, któremu zarząd składa swoje roczne sprawozdania finansowe. Nowe konsekrowane dziewice zostają włączone do stanu dziewic, a nie do diecezjalnego lub krajowego oddziału stowarzyszenia dziewic diecezji, w której zostały konsekrowane ${ }^{79}$. Trzeba jednak pamiętać, że jeżeli statut określonego stowarzyszenia dziewic nie respektuje celów realizowanych przez „ordo”, to takie

\footnotetext{
${ }^{75}$ ESI, nr 65.

${ }^{76}$ Kan. 298-311.

${ }^{77}$ Por. $298 \$ 1$; por. G. Ortega Gavara, La configuracion juridica del ordo virginum, s. 19.

78 Tamże.

${ }^{79}$ Tamże.
} 
stowarzyszenie jest tylko zwyczajnym stowarzyszeniem wiernych, ale nie stowarzyszeniem według kan. $604 \$ 2 \mathrm{KPK}$.

Bycie w stowarzyszeniu nie implikuje, że dziewice wspólnie mieszkają, mogą się zrzeszać, a nie mieszkć razem, albo mieszkać razem (nawet w sposób przejściowy) bez zrzeszania się z motywów przyjaźni, bliskości, wzajemnego wspierania się ${ }^{80}$.

Jeśli jednak grupa dziewic pragnie utworzyć stowarzyszenie życia wspólnego lub podobną do niego formę życia pod wspólną władzą i z własnym prawem, będzie musiała zwrócić się do Stolicy Apostolskiej o upoważnienie, aby ukonstytuować się jako nowa forma życia konsekrowanego zgodnie z kan. 605 KPK. Jasne jest jednak, że nie będzie to już stan dziewic, jak rozumiał go pierwotny Kościół. Będzie to nowa forma życia konsekrowanego, do zatwierdzania której jest uprawnieniona wyłącznie Stolica Apostolska, zgodnie z kan. 605.

\section{Podsumowanie}

Każdego roku na świecie poszerzają się szeregi dziewic konsekrowanych. Papieże, kongregacje rzymskie, konferencje episkopatów i poszczególni biskupi diecezjalni poświęcają wiele uwagi, także w aspekcie kanonicznym, temu odradzającemu się stanowi życia w Kościele. Dziewice w Kościele tworzą „stan” („ordo”), czyli pewien zorganizowany, w przeciwieństwie do życia pustelniczego, sposób życia, którego ani w przeszłości, ani obecnie nie określano tym terminem. Zmieniło się także pojmowanie przez Kościół dziewictwa. Obecnie akcent kładzie się nie na integralność fizyczną kobiety, ale na całkowite oddanie osoby Chrystusowi i służbie dla Królestwa. Stąd do konsekracji można dopuszczać dziewice żyjące w świecie, które nigdy nie zawierały małżeństwa ani nie żyły publicznie, czyli jawnie, w stanie przeciwnym czystości oraz według ogólnej opinii przez swój wiek, roztropność i obyczaje dają rękojmie, że wytrwają w życiu czystym oraz poświeconym służbie Kościołowi i bliźnim. Takie kryteria umożliwiają wielu kobietom, które odkryły swoje powołanie, spełniającym powyższe warunki, przystąpienie do stanu dziewic

\footnotetext{
${ }^{80}$ Por. Tamże, s. 20.
} 
konsekrowanych poprzez publiczną manifestację swojego świętego zamiaru w obrzędzie konsekracji dziewic wobec biskupa diecezjalnego, czy innego delegowane przez niego biskupa. Wcześniej jednak muszą, po odpowiedniej formacji, być przez tegoż biskupa dopuszczone do konsekracji.

Przez uroczysty obrzęd (Consecratio virginum) dziewica staje się osobą konsekrowaną, transcendentnym znakiem miłości Kościoła do Chrystusa, eschatologicznym obrazem tej niebieskiej Oblubienicy i przyszłego życia oraz zostaje włączona w służbę Kościoła, która przejawia się w modlitwie, pokucie, służbie braciom i pracy apostolskiej, stosownie do jej stanu i otrzymanych odpowiednich charyzmatów.

\section{The order of consecrated virgins. The right of virgins to associate. Legal and canonical aspect}

The aim of the article is to present the issue of consecrated virgins and their right to establish associations in the canon and liturgical aspect. The first part presents the historical aspect of consecrated virginity in the Church. In the second part, the definition of the state of consecrated virginity is thoroughly analyzed, while the third part is devoted to associations of consecrated virgins. The article ends with a summary and bibliography.

SŁOWA KLUCZOWE: dziewica; konsekracja; biskup diecezjalny; stan dziewic; „święty zamiar”

KEYWORDS: virgin; consecration; diocesan bishop; order of virgins; „holy resolution"

\section{Nota o AUTORZE}

Ks. DR HAB. JERZY ADAMCZYK - dr hab. nauk prawnych w zakresie prawa kanonicznego; wykładowca w WSD w Radomiu. 